\title{
Ovid and Illyricum*
}

\author{
SALMEDIN MESIHOVIĆ ${ }^{* *}$ \\ Faculty of Philosophy, University of Sarajevo
}

\begin{abstract}
The famed Roman poet Ovid was banished from Rome, for unknown reasons in $8 \mathrm{CE}$, by the first emperor Augustus, to the remote town of Tomis on the Black Sea coast, at the then-outmost eastern border of the Roman Empire. Ovid himself emphasised to have been banished for a mistake and a poem, but did not provide more elaborate details as to what the cause had exactly been. That was the period when the Roman Empire fought a difficult war against the Illyrian rebels and their military and political Alliance led by Bato the Daesitiate. For that reason, Ovid was sent to Tomis not through the Adriatic shore but rather through roundabouts, via Greece and Moesia. Ovid was very sad in Tomis, constantly pleading for amnesty. For that reason, he kept sending letters to influential friends and members of the ruling Augustus family, asking them to advocate for his return. In one of the letters to Germanicus, Ovid described in detail the triumphant procession honouring the victory over the rebelled Illyrians, mentioning also the captured Bato the Daesitate and the kind treatment he had received.
\end{abstract}

Key words: Ovid, Illyricum, Bato's War, Germanicus, Augustus

\section{Prisca iuvent alios, ego me nunc denique natum}

gratulor: haec aetas moribus apta meis ${ }^{1}$

Ovid (Publius Ovidius Naso 43 BCE - 17/18 CE) was the last representative of the "golden age" of the Roman poetry and the only of the glorious poets of the Augustus period that had more significantly reflected upon the then-province of

\footnotetext{
"The paper published as: “Ovidije i Ilirik”, Godišnjak Centra za balkanološka ispitivanja, knjiga 35, ANUBiH, Sarajevo 2008, 89 - 100.

"PhD. History Department. Email address: salmedin.mesihovic@ff.unsa.ba

${ }^{1}$ Ovid. Ars amat. III, 121 - 122 ("Ancient times may please some persons, but I thank myself for a timely nativity: this period fits my habits.")
} 
Illyricum and the Balkan world. ${ }^{2}$ His more prominent relationship was undoubtedly conditioned by all that was happening with the Roman Empire as a whole and with Ovid himself in the last decade of the Augustus period. Because of that, Ovid's more exhausting references to the Illyricum and the Balkan area are contained in his prose works Sorrows (Tristia) and Letters from the Black Sea (Epistulae ex Ponto).

In the spring of $6 \mathrm{CE}$, somewhere in the upper Bosnia region, a contingent of recruits from the civitates province of Illyricum that was supposed to be sent to the Marcomannic war, rebelled. The rebellion of the native soldiers had only been a lit fuse that had set the entire province on fire, causing the general uprising. That was the beginning of one of the most difficult wars that the Roman Empire fought, which lasted until the mid-September $9 \mathrm{CE}$, when the most important leader of the rebellion, Bato the Daesitiates, surrendered to Tiberius, the stepson of Augustus and the future emperor. ${ }^{3}$ In $8 \mathrm{CE}$, perhaps because of the case of Julia the Younger, Ovid was exiled to a far and secluded border town of Tomis at the Black Sea (today's Constanta). During his voyage to Tomis and during his stay there, Ovid wrote Tristia and Epistulae ex Ponto. ${ }^{4}$

Reasons behind Ovid's exile are unclear. Ovid himself stated that two faults had exiled him from the capital; a song and a fault (...duo crimina - carmen et error). ${ }^{5}$ Ovid was not exiled (exilium) but was cast out (relegatio), which was a milder punishment, without the loss of civil rights and without the confiscation of property. ${ }^{6}$

In that very difficult period for the Augustus regime, some of the emperor's own family members were banished. First, there was the final solution to the issue of Augustus' successor by the banishment of Agrippa Postumus, the last living son of Augustus' daughter Julia and general Marcus Vipsanius Agrippa, to the island of Pianosa, near Corsica. ${ }^{7}$ Agrippa Postumus' sister Julia the Younger (19 BCE - 28/29

${ }^{2}$ Illyricum, that which is of Illyricum and the Illyrian lands were mentioned also by Virgil (Enn. I, 242 - 249; Ecl. VIII, 6 - 8), Horatio (Car. I, 28; 21 - 22; II, 1, 12 - 15) and Propertius (I, 8, 1 - 26; II, 16, 1 - 56). It is interesting that Propertius' Illyricum does not match the then-province Illyricum. Propertius mentions the Illyrian regions (Orik, the Akroceraunian Cape) that were officially part of Macedonia and he most probably had in mind ethnic and historical, not the administrative substance of the area.

${ }^{3}$ On the Daesitiates, an Illyrian people, as well as on the Great Illyrian Uprising from 6 to 9 CE, as well as on the situation in the Roman Empire, see: Mesihović, 2007.

${ }^{4}$ On Ovid's exile and stay at the Black Sea (in the town of Tomis, today's Dobruja), as well as on Tristia and Ex Ponto, see: Introduction in Loeb's edition of Ovid's Tristia and Ex Ponto.

${ }^{5}$ Ovid. Tris. II, 207

${ }^{6}$ Budimir/Flašar, 1963, 408

${ }^{7}$ Vell. II, CXII, 7; Plin. NHVII, 149; Svet. Tib. 15; Cass. Dio LV, 32, 1-2; LVI, 1-2; Tac. Ann. I, 3; 5-6. He was banished most probably by $7 \mathrm{CE}$, or in early $7 \mathrm{CE}$, but most certainly before Germanicus' merger with Tiberius' western combatant group, since Dion speaks of the banishment of Agrippa Postumus immediately prior to mentioning Germanicus' arrival to Pannonia. Perhaps, judging by 
CE) also suffered her brother's fate. She was banished to a small island of Trimerus (today's Tremiti, Italy) in $8 \mathrm{CE}$ because she had broken the Augustus' morality code (adultery with senator Decimus Silanus). There she lived for 20 years. ${ }^{8}$ And perhaps the banishment of Ovid was linked to Julia the Younger's affair.' Sextus Aurelius Victor stated that Ovid was banished because of three books of The Art of Love (Ars Amatoria). ${ }^{10}$ Augustus most probably did not like the poetic and social activity of this poet who was of sophisticated and elegant eroticism (popular with higher circles of the roman society), since it had contradicted with the morality codes and the family laws.

Ovid arrived to Tomis by sea, via Greece to Thrace (see Tristia and Ex Ponto), since the connection by land had still been blocked by the rebels at the time. Ovid had travelled quite a long time, with frequent and long halts at a number of places, probably hoping that Rome would pardon him. Tomis (today's Constanta) was a Miletus colony founded on the shores of the Black Sea, but, in Ovid's time, that ultimate border of the civilised world (Scythia Minor, today's Dobruja) and the Roman Empire was extensively intertwined with the Getan and Sarmatian elements. In Tomis, Ovid was not short of material goods, but he did feel an expressed want for his homeland. A supreme intellectual of the Augustan Rome, he learnt both the Getic and the Sarmatian language, and was proficient to an extent that he even wrote poetry in Getic.

Ovid was born in Sulmo (present-day Sulmona) in the land Peligna (perhaps originally of the Illyrian settlers of the east coast of the Adriatic). He was a member of a distinguished and wealthy family, and unlike Vergil or Horace, even Propertius, who were born decades earlier, he was a man who came from and lived in the Augustus' peace. He was quick to change his rhetoric with poetry and he "sang love poetry filled with eroticism". He wrote the following works: a collection of love elegies Amores (Loves); Heroides, a tragedy; the Medea, a lost tragedy; Ars Amatoria (The Art of Love); Medicamina faciei or De medicamine faciei (Cosmetics of the Face), a poem preserved in fragments; Remedia Amoris (Love's Remedy); Metamorphoses; Fasti (The Book of Days); a lost work Liber in malos poetas (The

Velleius (II, CXII, 7), the banishment could have occurred in $6 \mathrm{CE}$, and, if not the banishment, then most certainly the process of falling out of mercy. For Agrippa Postumus and his mother Julia the Elder the affairs of Lucius Aduasius and Azinius Epicadus are linked, since they wanted to forcibly bring to the armies the mother and son from the places where they had been banished. Svet. Aug. 19. Perhaps Iunius Novatus' plebeian may have been involved in the entire affair, for he had issued a highly offensive letter against Augustus on behalf of Agrippa Postumus. Iunius Novatus was punished only financially. Svet. Aug. 51

${ }^{8}$ Tac. Ann. IV, 71

${ }^{9}$ Budimir/Flašer, 1963, 407.

${ }^{10}$ Sex. Aur. Vic. epi. I, 24 
Book against Bad Poets); the already-mentioned Tristia and Epistulae ex Ponto; the poem Ibis; an allegory Nux (A Nut); an unfinished poem about fishery (Halieutica); a lost work Consolatio ad Liviam; lost poems in the Getic language. In exile, he most probably also translated Arati's Phenomena. ${ }^{11}$

During the transition between two eras and in the years that followed, Ovid was, undoubtedly, a famous person in the then-Roman society and his verses carried weight and were able to initiate some highly positioned and distinguished persons of both sexes to take certain activities Augustus most certainly would not have approved. It was in the years when he was banished that he wrote Ars Amatoria and Metamorphoses, and he had already made significant progress with the Book of Days that he never completed. That work is famous for its frivolous eroticism and even immoral content, which was in a direct contrast with the promoted "family values". Perhaps it was because of his works Metamorphoses and Fasti that he was conditioned to get as further away as possible from his reputation of the poet of erotic love and become closer to the ideas of the Augustus' regime, since both works were written after he had completed his love elegies and erotic poetry. However, it seems that he failed in doing so, and the karma of an immoral poet continued to follow him, the poet who was able to initiate people to do things that were not in accordance with Augustus' family laws or were directly breaking them. In the first two years of the Illyrian revolt, which were critical for the ruling regime, ${ }^{12}$ the degree of tolerance of the very regime inevitably had to drop, and one of the victims was Ovid himself.

Most complete and detailed data on the Illyrian history Ovid left in his letter to Germanicus (Epistulae ex Ponto, II, I). ${ }^{13}$ The letter was most probably written in the first months of year $13 \mathrm{CE}$. It describes in details Tiberius' triumph over Dalmatians and Pannonians. ${ }^{14}$ Tiberius most probably celebrated the triumph on 23 October $12 \mathrm{CE},{ }^{15}$ or on 16 January $13 \mathrm{CE} .{ }^{16}$ The triumph is also mentioned by the contemporary Valleius Patreculus ${ }^{17}$ (in more detail; the description was written at least 15 years after that of Ovid), and, in less detail, by Suetonius ${ }^{18}$ and Cassius

${ }^{11}$ On Ovid's work, see: Budimir/Flašar, 1963, 406 - 429; Rodgers/Dodge, 2006, 388 - 389

${ }^{12}$ See more on that in: Mesihović, 2007, $314-617$

${ }^{13}$ Ovid. Ex Ponto, II, I (Germanico), 1 - 68; Ovid's letters from the Black Sea, in the context of the scientific research of the 6-9 CE rebellion have remained completely neglected, and to this very day they have not been analysed regarding the relationship towards the rebellion, but were briefly mentioned by Willian Smith $(1867,475)$.

${ }^{14}$ On the triumph (that had been postponed because of the Teutoburg catastrophe), see: Mesihović, 2007, 404; $555-557 ; 601-611$

${ }^{15}$ Zaninović, 1996, 212

${ }^{16}$ Introduction in Leob's edition of Ovid's Tristia and Ex Ponto, xxxiv - xxxv

${ }^{17}$ Vell. II, CXXI, 2-3

${ }^{18}$ Svet. Tib. 17; 20. 
Dio. ${ }^{19}$ The description of Tiberius triumph can also be seen on the low-relief cameo, known as Gemma Augustea.

The letter to Germanicus was written in a pathetic, almost desperately submissive tone, and the main idea behind it was to influence Germanicus, as well as other members of the ruling family, to treat Ovid mercifully and enable his return to Rome and Italy. In view of the content, the letter can be divided into three sections: 1. introduction that is abundant with laudation; 2. a more detailed description of the triumph; 3. the closing part, directly addressing Germanicus, also in the form of an exaggerated laudation.

Although less present in the second part, the laudation and the pathetic content can still be observed in the second part. The description of the celebration of the triumph is picturesque, and Ovid paid tribute to Bato the Daestitiate. And, if we were not to observe Ovid's "submissive" style, we will see the facts about the triumph that are, most probably, credible. Ovid did not personally witness the triumph, but, judging by the data he presented, he was well-informed about it, as well as about the fate of the imprisoned rebel leaders. Ovid is grateful to the glory (or the public, or the public voice, or the story) for witnessing the magnificent triumph although he had been imprisoned among the Geats. This is a proof that the news from Rome were rather detained and that they reached the outmost parts of the Empire, and also that the rebellion and the events related to it was a more or less known fact throughout the Roman Empire. It is possible that Ovid got a letter from his male/female friend who witnessed the triumph, for the description was rather too meticulous to be considered founded on a passing piece of information or on the information that would come from the individuals arriving to the Black Sea.

Ovid also explicitly mentions Bato, who, as the most valuable prisoner of war, was processed in the triumph. ${ }^{20}$ Ovid was much more precise regarding the issue in comparison to other literary sources, and he clearly states that the majority of the rebel leaders, processed in the triumph, were spared and that they were pardoned. ${ }^{21}$

${ }^{19}$ Cass. Dio LVI, 17, 1-18, 1

${ }^{20}$ Ovid. Ex Ponto, II, I (Germanico), 1-68. Judging by Ovid's description, Tiberius' triumph from 12 or $13 \mathrm{CE}$ over Illyrians was similar to Germanicus' triumph of 26 May year $17 \mathrm{CE}$, over the Germanic peoples Heruli, Chatti, Angrivarii, as well as other tribes all the way to Elba (Strab. Geo. VII, 1, 4; Tac. Ann. II, 41). Ovid's account of the triumph states that the depictions of the conquered regions, rivers and mountains in the pacified land, as well as depictions of the fight in thick forests, were displayed.

${ }^{21}$ Ovid. Ex Ponto, II, I (Germanico), 43 - 46. Also, Velleius Paterculus (II, CXXI, 3) mentions the processing of the chained imprisoned rebel leaders in a triumphant procession (Quippe omnis eminentissimos hostium duces non occisos fama narravit, sed vinctos triumphus ostendit), but he does not mention their pardon. Unlike Paterculus, Suetonius (Tib. 20) does not mention the procession of the rebel leaders, but he does mention that Bato was pardoned and repatriated to Ravena with lavish gifts. Still, both the sources confirm Ovid's data (Ex Ponto, II, I, 30) that the Roman commanders from the $6-9 \mathrm{CE}$ war were rewarded. 
Ovid described the day of the triumph as sunny, presenting an array of data about the prisoners, the conquered fortifications (oppida); he even went as far as to describe people in the fortifications, rivers and mountains of the conquered land, as well as battles in thick forests. The description of Germanicus' victories in the triumph is also interesting. Ovid's detailed descriptions of prisoners and the triumphant procession, as well as mentioning Bato the Daesitiate, all had a clear purpose. By this, Ovid wanted to show that mercy was shown to the biggest enemy of the empire, which he directly states, while he was still condemned to stay in a neglected corner of the Empire, a Siberia of Ovid's time.

Also, in Tristia and Ex Ponto, Ovid presents more data that concern the events in the West Balkans in the period from 6 to $9 \mathrm{CE}$. That should not be a surprise given the fact that he lived in the period of the rebellion, and that the most traumatic events related to Ovid took place parallel to the event. In the second book of Sorrow, again praising Augustus in a desperate attempt to receive his mercy, Ovid mentions Pannonia and the Illyrian shore. ${ }^{22}$ It is interesting that in the same part of the second book of Sorrow, there were verses of Ovid's attempt of redemption. ${ }^{23}$ Ovid mentioned the triumph one more time, in his letter to Vallerius Messallinus. ${ }^{24}$ Only, in this case, it is the mentioning of the triumph as another laudatios element

${ }^{22}$ Ovid. Tristia, II, 225

${ }^{23}$ Ovid. Tristia, II, 207 - 224

${ }^{24}$ Ovid. Ex Ponto, II, II (Messalino), 75-80. Vallerius Messallinus, Ovid's friend, was a consul in 3 BCE. Vallerius Messallinus (full name: Marcus Valerius Messalla Messallinus) was the son of a Roman general, orator and historian of the civil wars, Marcus Vallerius Messalla Corvinus (64 BCE $-8 \mathrm{CE}$ ). On his role in the civil wars from 41 to 31 BCE. App. de bell. civ. IV, 38, 136; V, 102103; 109; 112-113; Vell. II, LXXI, 1; Cass. Dio XLVII, 11, 4. In the Roman society, Ovid was most probably in the client-patron relationship. One of his most prominent patrons was Marcus Vallerius Messalla Corvinus. It is interesting that he too (who served as a consul suffectus in 31 BCE instead of Mark Antony) was highly engaged in the Octavianus' campaign of 35-33 BCE, and was the one who had finally submitted the militant and irreconcilable Salas. (App. Ill. 17; Cass. Dio XLIX, 38, 3). Messalla Corvinus, just like Maecenas, had his poetic circle, the member of which was Tibullus. Smith W., 1867, 1051-1051; Budimir-Flašar, 1963, 294; 381-382; Mirković, 2003 , 44. In his circle, that had still assembled some lower-quality poets, was also a female poet, Sulpicia, the daughter of Sulpicius Rufus, most probably the niece of Messalla Corvinus. Vallerius Messallinus was the second husband of Claudia Marcella Minor, Octavius' daughter (the sister of Augustus) from her first marriage. This marriage produced Marcus Valerius Messala Barbatus Messallinus, whose daughter from his marriage to Domitia Lepida was Messalina (20-48 CE), the third wife of Claudius. Vallerius Messallinus had a biological brother (adopted by their mother's brother) Marcus Aurelius Cotta Messallinus Maximus). Vell. II, CXII, 2; also see: Introduction in Loeb's edition of Tristia and Ex Ponto, xii. On Messalla Corvinus and his sons Messallinus and Cotta and his patronal and friendly relationship with Ovid, see: Introduction to Loeb's edition of Ovid's Tristia and Ex Ponto, xi-xiii. Vallerius Messalinus was a prominent Roman commander in the time of the Great Illyrian Revolt and, owing to his commandership over the $20^{\text {th }}$ legion, the rebels, led by Bato the Daesitiate himself, were prevented from penetrating the west in the summer of 6 CE (see: Mesihović, 2007). 
in the glory of Augustus and Augustus' house (...Augustae membra valere domus ${ }^{25}$ ). Thus, the most erotic of Roman poets presented in his work some valuable historical data on Illyrians, about the turning point for them, when the lands in the West Balkan interior finally entered the period of historical antiquity. After Augustus' death (19 August $14 \mathrm{CE}$ ), the new emperor Tiberius remained relentless regarding Ovid's exile, hence the Roman poet died in 17 or $18 \mathrm{CE}$ in the remote Tomis, far away at the Black Sea.

Ovid mentioned "the Illyrian" in several other instances. He especially emphasised the black Illyrian tar, in two places. ${ }^{26}$ Ovid's tar was most probably pine resin that was produced through distillation of oil and coal, most probably for the same purpose. This clearly shows that the West Balkan forests were the most important base for raw materials between two eras, and that Illyrians were experts in that "craft", which undoubtedly speaks of an exceptionally technical involvement of the Illyric population, especially the people living in the coniferous forests. Ovid's verses 563-603 of the fourth book of the Transformations are also very valuable for Illyric mythology, where he speaks of Cadmus' and Harmonia's transformation into serpents.

Ovid. Ars amat. II, 657 - 660

“...Nominibus mollire licet mala: fusca vocetur,

Nigrior Illyrica cui pice sanguis erit :

Si straba, sit Veneri similis: si rava, Minervae:

Sit gracilis, macie quae male viva sua est;...”

\section{Ovid. Metamorphoses, IV, 563 - 603}

"Nescit Agenorides natam parvumque nepotem aequoris esse deos; luctu serieque malorum

victus et ostentis, quae plurima viderat, exit

conditor urbe sua, tamquam fortuna locorum, non sua se premeret, longisque erroribus actus contigit Illyricos profuga cum coniuge fines. iamque malis annisque graves dum prima retractant fata domus releguntque suos sermone labores,

\footnotetext{
${ }^{25}$ Ovid. Ex Ponto, II, II ( Messalino ), 74

${ }^{26}$ Ovid. Ars amat. II, 657 - 660 ; Ovid. Ex Ponto, IV, XIV (Tuticano), 45 - 48
} 
'num sacer ille mea traiectus cuspide serpens'

Cadmus ait 'fuerat, tum cum Sidone profectus

vipereos sparsi per humum, nova semina, dentes?

quem si cura deum tam certa vindicat ira,

ipse precor serpens in longam porrigar alvum.'

dixit, et ut serpens in longam tenditur alvum

durataeque cuti squamas increscere sentit

nigraque caeruleis variari corpora guttis

in pectusque cadit pronus, commissaque in unum

paulatim tereti tenuantur acumine crura.

580

bracchia iam restant: quae restant bracchia tendit

et lacrimis per adhuc humana fluentibus ora

'accede, o coniunx, accede, miserrima' dixit,

'dumque aliquid superest de me, me tange manumque

accipe, dum manus est, dum non totum occupat anguis.'

585

ille quidem vult plura loqui, sed lingua repente

in partes est fissa duas, nec verba volenti

sufficiunt, quotiensque aliquos parat edere questus,

sibilat: hanc illi vocem natura reliquit.

nuda manu feriens exclamat pectora coniunx:

590

'Cadme, mane teque, infelix, his exue monstris!

Cadme, quid hoc? ubi pes, ubi sunt umerique manusque

et color et facies et, dum loquor, omnia? cur non

me quoque, caelestes, in eandem vertitis anguem?'

dixerat, ille suae lambebat coniugis ora

inque sinus caros, veluti cognosceret, ibat

et dabat amplexus adsuetaque colla petebat.

quisquis adest (aderant comites), terretur; at illa

lubrica permulcet cristati colla draconis,

et subito duo sunt iunctoque volumine serpunt,

600

donec in adpositi nemoris subiere latebras,

nunc quoque nec fugiunt hominem nec vulnere laedunt

quidque prius fuerint, placidi meminere dracones." 


\section{Ovid. Tristia, II, 225}

“..nunc tibi Pannonia est, nunc Illyris ora domanda,

Raetica nunc praebent Thraciaque arma metum..."

\section{Ovid. Ex Ponto, II, I (Germanico)}

"Huc quoque Caesarei peruenit fama triumphi,

languida quo fessi uix uenit aura Noti.

Nil fore dulce mibi Scythica regione putaui:

iam minus hic odio est quam fuit ante locus.

Tandem aliquid pulsa curarum nube serenum

uidi fortunae uerba dedique meae.

Nolit ut ulla mihi contingere gaudia Caesar,

uelle potest cuiuis haec tamen una dari.

Di quoque, ut a cunctis hilari pietate colantur,

tristitiam poni per sua festa iubent.

Denique, quod certus furor est audere fateri,

hac ego laetitia, si uetet ipse, fruar.

Iuppiter utilibus quotiens iuuat imbribus agros,

mixta tenax segeti crescere lappa solet.

Nos quoque frugiferum sentimus inutilis herba

numen et inuita saepe iuuamur ope.

Gaudia Caesareae mentis pro parte uirili

sunt mea: priuati nil habet illa domus.

Gratia, Fama, tibi per quam spectata triumphi

incluso mediis est mihi pompa Getis!

Indice te didici nuper uisenda coisse

innumeras gentes ad ducis ora sui,

quaeque capit uastis inmensum moenibus orbem,

hospitiis Romam uix habuisse locum.

Tu mibi narrasti, cum multis lucibus ante

fuderit adsiduas nubilus auster aquas,

numine caelesti solem fulsisse serenum

cum populi uultu conueniente die 
atque ita uictorem cum magnae uocis honore

bellica laudatis dona dedisse uiris

claraque sumpturum pictas insignia uestes

tura prius sanctis inposuisse focis

Iustitiamque sui caste placasse parentis,

illo quae templum pectore semper habet,

quaque ierit, felix adiectum plausibus omen

saxaque roratis erubuisse rosis;

protinus argento uersos imitantia muros

barbara cum pictis oppida lata uiris

fluminaque et montes et in altis proelia siluis

armaque cum telis in strue mixta sua

40

deque tropaeorum quod sol incenderet auro

aurea Romani tecta fuisse fori

totque tulisse duces captiuos addita collis

uincula paene hostis quot satis esse fuit.

Maxima pars horum uitam ueniamque tulerunt,

in quibus et belli summa caputque Bato.

Cur ego posse negem minui mibi numinis iram,

cum uideam mitis hostibus esse deos?

Pertulit hic idem nobis, Germanice, rumor

oppida sub titulo nominis isse tui

atque ea te contra nec muri mole nec armis

nec satis ingenio tuta fuisse loci.

Di tibi dent annos! A te nam cetera sumes,

sint modo uirtuti tempora longa tuae.

Quod precor eueniet_-sunt quaedam oracula uatum-,

nam deus optanti prospera signa dedit.

Te quoque uictorem Tarpeias scandere in arces

laeta coronatis Roma uidebit equis

maturosque pater nati spectabit honores

gaudia percipiens quae dedit ipse suis.

60

Iam nunc haec a me, iuuenum belloque togaque 
maxime, dicta tibi uaticinante nota.

Hunc quoque carminibus referam fortasse triumphum,

sufficiet nostris si modo uita malis,

inbuero Scythicas si non prius ipse sagittas

abstuleritque ferox hoc caput ense Getes.

Quae si me saluo dabitur tua laurea templis,

omina bis dices uera fuisse mea."

\section{II, II (Messalino)}

“...Adde triumphatos modo Paeonas, adde quietis

subdita montanae brachia Dalmatiae.

Nec dedignata est abiectis Illyris armis

Caesareum famulo uertice ferre pedem..."

\section{IV, XIV (Tuticano)}

"...Adde quod, Illyrica si iam pice nigrior essem,

non mordenda mibi turba fidelis erat.

Molliter a uobis mea sors excepta, Tomitae,

tam mites Graios indicat esse uiros..."

\section{Bibliography}

\section{Abbreviations}

LCL The Loeb Classical Library, London: William Heinemann LTD - Cambridge Mass.: Harvard University Press

$\mathrm{MH}$

Matica Hrvatska, Zagreb.

\section{Publications of Sources}

Apijan 1863.: Apijan, Ilirike, Ante Starčević. Zagreb: Danica Ilirska.

Apijan 1899.: Appian, The Foreign Wars, The Illyrian Wars. http://www.perseus. tufts.edu/, bazirano na ed. Appian. The Foreign Wars. Horace White. New York: The Macmillan Company.

Apijan 1879.: Appiani, Historia Romana. Ludovicus Mendelssohn, Lipsiae: Teubneri 
Apijan 2005.: Marjeta Šašel Kos, Appian and Illyricum, Situla 43, Ljubljana: Narodni muzej Slovenije, 52 - 81 .

Apijan 1967.: Apijan, Gradanski ratovi. Bogdan M. Stevanović, Beograd: Kultura. Horacije.: Horace, Volume I. Odes and Epodes. Niall Rudd, LCL.

Kasije Dion 1954-1955.: Dio js Roman History in nine Volumes. Earnest Cary, LCL (2).

Ovidije 1924.: Ovid, Tristia. Ex Ponto. A. L. Wheeler, LCL.

Ovidije 1977.: 1984.: Ovid, Metamorphoses. Frank J. Miller, LCL.

Ovidije 1979.: Ovid. Art of Love. Cosmetics. Remedies for Love. Ibis. Walnut-tree. Sea Fishing. Consolation J. H. Mozley, LCL.

Plinije Stariji 1866.: Naturalis historia, Berlin: ed. Weidmannos.

Propercije 1988.: Propertius, Elegies, G. P. Goold, LCL.

Sekst Aurelije Viktor; Sextus Aurelius Victor, edd. F.Pichlmayr i R. Gruendel, Leipzig.

Sekst Aurelije Viktor.: Sextus Aurelius Victor, www.thelatinlibrary.com

Sekst Aurelije Viktor 2000.: A Booklet About the Style of Life and the Manners of the Imperatores. Abbreviated from the Books of Sextus Aurelius Victor. Thomas M. Banchich, Buffalo, New York: Canisius College.

Svetonije 1978.: Gaj Svetonije Trankvil, Dvanaest rimskih careva, Stjepan Hosu, Zagreb: Naprijed.

Strabon 1954.: The Geography of Strabo, H. L. Jones, LCL.

Tacit, Anali,1970.: Tacit, Anali, Jakov Kostović, Zagreb: MH.

Velej Paterkul 1955.: Velleius Paterculus, Compendium of Roman History, Frederick W. Shipley, LCL.

Vergilije.: Virgil, Volume I Eclogues. Georgics. Aeneid, H. Rushton Fairclough, LCL. Vergilije 2005.: Vergilije, Eneida, Bratoljub Klaić, Zagreb: Globus media.

\section{Literature}

Budimir, M. / Flašar, M. 1963, Pregled rimske književnosti, De auctoribus romanis. Beograd.

Mesihović, S, 2007, Dezitijati, Sarajevo (u rukopisu). Dopunjena verzija doktorske disertacije: Dezitijati: kulturna i narodnosno-politička zajednica u Iliriku i osvajanja Oktavijanova doba. Zagreb. 
Mirković, M. 2003, Rimska država u doba principata i dominata (27. pre Hr.-337. n.e.), Od Avgusta do Konstantina. Beograd: Dosije.

Rodgers, N. / Dodge, H. 2006, Ancient Rome. London: Anness Publishing.

Smith, W. 1867, Dictionary of Greek and Roman Biography and Mythology. Boston: Little, Brown and Company.

Smith, W. 1870, Dictionary of Greek and Roman Antiquities. Boston: Little, Brown and Company.

Zaninović, M. 1996, Od Helena do Hrvata. Zagreb: Školska knjiga, 